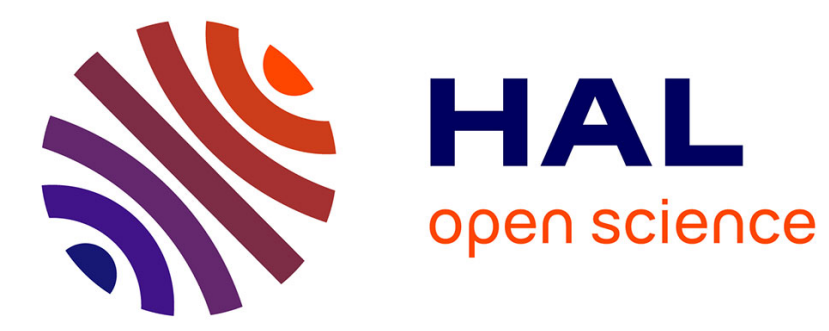

\title{
Interruptions in Surgery: A Comprehensive Review
}

Maxime Bretonnier, Estelle Michinov, Xavier Morandi, Laurent Riffaud

\section{To cite this version:}

Maxime Bretonnier, Estelle Michinov, Xavier Morandi, Laurent Riffaud. Interruptions in Surgery: A Comprehensive Review. Journal of Surgical Research, 2020, 247, pp.190-196. 10.1016/j.jss.2019.10.024 . hal-02364092

HAL Id: hal-02364092 https://hal-univ-rennes1.archives-ouvertes.fr/hal-02364092

Submitted on 11 Dec 2019

HAL is a multi-disciplinary open access archive for the deposit and dissemination of scientific research documents, whether they are published or not. The documents may come from teaching and research institutions in France or abroad, or from public or private research centers.
L'archive ouverte pluridisciplinaire HAL, est destinée au dépôt et à la diffusion de documents scientifiques de niveau recherche, publiés ou non, émanant des établissements d'enseignement et de recherche français ou étrangers, des laboratoires publics ou privés. 


\section{Interruptions in Surgery: a comprehensive review}

\section{Interruptions in surgery}

Maxime Bretonnier $^{\mathrm{a}, \mathrm{b}}$, Estelle Michinov ${ }^{\mathrm{c}}$, Xavier Morandi ${ }^{\mathrm{a}, \mathrm{b}}$, Laurent Riffaud ${ }^{\mathrm{a}, \mathrm{b}}$

a Univ Rennes, INSERM, LTSI - UMR 1099, F-35000 Rennes, France

b Department of Neurosurgery, Pontchaillou University Hospital, 2, rue Henri Le Guilloux, 35033 Rennes Cedex 9, France

c Univ Rennes, LP3C (Laboratoire de Psychologie : Cognition, Comportement, Communication) - EA 1285, F-35000 Rennes, France

Authors e-mail adresses: maxime.bretonnier@chu-rennes.fr ; estelle.michinov@univ-rennes2.fr ; xavier.morandi@chu-rennes.fr ; laurent.riffaud@chu-rennes.fr

Corresponding author: Dr M Bretonnier, Department of Neurosurgery, Pontchaillou University Hospital, 2, rue Henri Le Guilloux, 35033 Rennes Cedex 9, France (e-mail: maxime.bretonnier@churennes.fr)

telephone: + 332992842 77, facsimile: + 33299284180

Author contributions:

M Bretonnier: literature search, study conception

E Michinov: literature search, critical revision

X Morandi: critical revision

L Riffaud: supervision

Declaration of interest: none 


\begin{abstract}
Background: Recent literature showed that analysis of interruptions can contribute to evaluating the care process in the operating room and thus understanding potential errors which may occur during surgical procedures. The aim of this comprehensive review was to summarize current knowledge on the description and impact of interruptions in surgery.
\end{abstract}

Material and methods: A literature search was conducted according to a set of criteria in the databases MEDLINE, BASE, Cochrane's Library and PsycINFO.

Results: 41 articles were included. 2 main methodological approaches were found, observational in the OR, or controlled in an experimental simulated environment. Interruptions in the OR were manifold and several classifications were used. The severity of interruptions differed according to the category of the interruptions. Interruptions were influenced by team familiarity and the expertise of the surgical team; high team familiarity and a high level of expertise decreased the frequency of interruptions. However, our literature search lacked controlled studies carried out in the OR. Interruptions seemed to increase the workload and stress of the surgical team and impair non-technical skills, but no clear evidence of this was advanced.

Conclusions: Interruptions are probably risk factors for errors in the operating room.

However, there is as yet no clear evidence of the association of interruption frequency with errors in the operating room. There is a need to define and target interruptions which should be reduced, by putting safeguards in place, thereby allowing those which could be beneficial and neglecting those with no potential consequences.

Keywords: surgery ; interruptions ; disruptions ; safety 


\section{Introduction}

In 1999, the United States Institute of Medicine published a report distinguishing medical errors as the 8th leading cause of death in that country $\left(98,000\right.$ deaths a year). ${ }^{1}$ Surgical disciplines are largely concerned by these errors and up to $66 \%$ of medical adverse effects, defined as the occurrence of an undesired effect after treatment, are related to a surgical procedure. ${ }^{2,3}$ Because of the increased risk of morbidity and mortality during a surgical procedure, investigations into quality and safety issues in the operating room (OR) were conducted. The OR is a complex work environment, this research therefore involved multidisciplinary teams including human factor, ${ }^{4}$ psychologist, ${ }^{5}$ management, ${ }^{6}$ and ergonomic $^{7}$ researchers.

There exist effective tools to assess quality and safety in the OR: adverse event measurement allows identification of potential errors in the surgical process, ${ }^{3}$ workload and stress assessment by validated scales points out their negative impact on surgical performance. ${ }^{8,9,10}$ It is now accepted that errors resulting from adverse events are mainly secondary to a lack of non-technical skills (NTS). ${ }^{4}$ NTS are divided into cognitive (situation awareness, mental readiness, assessing risks...) and interpersonal (communication, leadership, teamwork, planning...) skills. ${ }^{11}$

Interruptions are defined as incidents or occurrences preventing the worker from progressing in his primary task. ${ }^{6}$ They constitute a well-studied phenomenon in occupational psychology and management, and their analysis is essential to evaluate the care process in the OR and to understand errors arising during surgical procedures. In the particular context of surgery, an interruption can be defined as a deviation in the normal course of the surgical procedure or surgical workflow. Interruptions at the work place can be differentiated into several types: intrusions, breaks, distractions, discrepancies. ${ }^{6}$ They may have both positive and negative consequences but they are mainly described as harmful in the literature. They 
impair quality of work and well-being and increase workload and time of completion, ${ }^{12-15}$ particularly if the work task is complex. ${ }^{16-19}$ However, the negative impact of interruptions is not obvious for repetitive tasks: they accelerate the achievement of the main task without damaging the quality of work. ${ }^{7,13}$ The impact of interruptions also depends on the worker's expertise: interruptions cause a poorer quality of work and an increased completion time for a novice when compared to an expert. ${ }^{6,19}$

Interruptions in surgical procedures have been examined in numerous studies, both in the OR and in simulated environments. Information acquired from these studies needs to be analyzed and summarized, since their methodologies and results were heterogeneous. A systematic review was published in 2016, but this study focused solely on distractions: these only represent a portion of the interruptions, which is why this literature review included only 17 studies. ${ }^{20}$ No other review on the description and impact of interruptions on surgical procedure has been published.

Through this comprehensive review, we aimed to summarize current knowledge on the description and impact of interruptions on surgical procedures. We first described interruptions particularities in surgery and then focused our description on their consequences. Particular emphasis has been placed on trying to understand how interruptions can impair NTS and potentially threaten safety in the OR.

\section{Material and methods}

We conducted a comprehensive review of the literature. Two investigators (first and second authors) independently carried out literature searches in the databases MEDLINE, BASE, Cochrane's Library, PsycINFO in December 2018, without restriction of date of publication. The following keywords were searched: "surg*” or "operating room*” or 
“operating theatre*” or "task" or "work" and “interrupt*” or "distract*” or "disrupt*”. Articles whose titles and abstracts were related to interruptions in surgery were reviewed. Inclusion criteria were: studies published in English, retrospective and prospective studies, reviews, studies carried out in the OR or in a simulated environment, studies whose main or secondary outcomes were descriptions and evaluation of the impact of interruptions on the surgical procedure or the surgical team. Exclusion criteria were: studies focusing on interruptions of the anaesthetic team. After reading eligible articles, we checked the references of those selected in order to enlarge our research to other relevant articles. Each article fulfilling the inclusion criteria was included in our review, the validity of the studies was assessed by the two investigators and consensus between them was used to resolve any disagreement.

Quality assessment of studies was evaluated using the NIH Quality Assessment Tool for Observational Cohort and Cross-Sectional Studies. ${ }^{21}$ Quality assessment was carried out by both first and second authors. This tool permitted the evaluation of key method points for the studies included, in particular the definition of the research question and the population studied, the justification of the sample size, the inclusion/exclusion criteria.

\section{Results}

The flow diagram of our literature search is displayed in Figure A. Our review included 41 studies dealing with interruptions and surgery.

\section{Studies’ methodology}

Two main methodological approaches have been reported:

-An observational approach in a natural environment for 15 studies. ${ }^{22-36}$ The goals were to quantify and characterize interruptions according to their type and impact on the surgical team. Some studies evaluated correlations between interruptions and NTS performance, workload or stress. ${ }^{30,31}$ 
-An experimental approach in a simulated environment for 15 studies. ${ }^{37-51}$ Comparisons were made between an experimental and a control group during surgical simulation were performed. For example, two groups carried out the same task, during which one of the two was interrupted (by a distraction or a secondary task). Judgment criteria varied: frequency of errors, time of realization, evaluation of workload, learning of technical gesture.

Other studies using different methodological approaches were published:

-Development and validation of interruption measurement tools useful for research were reported in 7 studies. ${ }^{52-58}$ These studies used interruption classifications, or interruption severity scores. One study developed a score which calculated the impact of interruptions reported by surgical staff after surgery. ${ }^{53}$

-2 retrospective observational studies were performed: they described interruptions reported by medical and paramedical staff. ${ }^{59,60}$

• One interventional study tested a measure of interruption reduction in the OR. ${ }^{61}$ Five phases of risk were defined during a surgical procedure (anesthesia induction, surgical briefing, specimen collection, final surgical counts and debriefing, anesthesia emergence). The staff was educated to reduce interruptions during these 5 phases. Results showed a significant decrease in recorded noise level during these 5 phases after staff education.

-A systematic review of the impact of interruptions on surgical performance was published in 2016 including 17 articles. This study did not deal with the impact of interruptions on NTS. ${ }^{20}$

\section{Categories of interruptions}


Table A summarized all the studies carried out in the OR whose primary or secondary objective was description of interruptions. Quality assessment of studies is reported.

Numbers of interruptions per hour varied from one study to another and ranged from 2.4/h to $114 / \mathrm{h}$. However, classification of interruptions differed between studies. This rendered impossible the comparison of studies in terms of numbers of interruptions and categories observed. For example, some studies focused only on interruptions related to communication issues. $^{23,25}$

The most common categories of interruptions were: communication issues, ${ }^{22,27,30,31,33,34,36,57}$ telephone/beeper, ${ }^{26,30,55-57}$ entrances and exits, ${ }^{26,29,30,33,34}$ intrusions by outside personnel, ${ }^{24,31}$ equipment issues, ${ }^{27,32,52}$ work environment issues, ${ }^{52,57}$ movements around the monitors, ${ }^{52,56}$ procedural issues, ${ }^{33,52}$ distractions, ${ }^{36,54}$ teamwork issues, ${ }^{24}$ and supervision/training. ${ }^{49}$

\section{Severity of interruptions}

Severity or interference of interruptions was also studied. This was defined as the effect of interruptions on the surgical workflow, classified by the observer. Several scales were used to measure the interference or severity of interruptions: these are reported in Table A. The scales were established on the same principle in the majority of studies. Interference ranked from absence of impact on the workflow up to the complete cessation of the surgical procedure (an example of classification is shown in Table B). ${ }^{25-27,29-31,33-35,52,55-57}$ Other studies used different methods to assess the interference of interruptions. Lingard et al. classified the observed effects of communication failures (detailed in Table A). ${ }^{23}$ Zheng et al. and Henaux et al. demonstrated a considerable increase in surgical procedure duration caused by interruptions. $^{22,36}$ 
Interruptions with the highest rates on scales of severity were: malfunction/shortage of equipment issues, ${ }^{26,29-31,33,52,55-57}$ procedural issues (i.e. intrinsic to the surgical procedure), ${ }^{29-}$ $31,52,56,57$ work environment issues, ${ }^{26,52,56}$ communication issues, ${ }^{27,29,31,57}$ distractions $^{57}$ and changes of instruments. ${ }^{22,33}$ The most severe interruptions were not the most frequent.

\section{Timing of interruptions during the surgical procedure}

Three studies presented data on the onset of interruptions during the intraoperative phase (from incision to closure). Their results were concordant as the majority of interruptions were observed at the beginning of the procedure. Antoniadis et al. showed that interruptions were significantly more frequent in the first quarter of the surgical procedure. ${ }^{26}$ Morgan et al. reported that their number was constant during the first 3 quarters and then decreased. ${ }^{54}$ Yoong et al. found that $90 \%$ of interruptions occurred during the first 30 minutes. ${ }^{35}$

Data concerning the precise phase of the surgical procedure were not specified.

\section{Protagonists of interruptions}

Seven studies performed in the OR described the groups of protagonists as the source or the target of interruptions. The OR staff was divided into 3 groups: "anesthesia” (anesthesiologist, nurse anesthetists), “surgical” (surgeon, assistant), "nurse” (scrub and circulating nurse). ${ }^{25-29,31,36,56}$ These studies led to the following conclusions:

-All groups could be a source or a target of interruptions

-Proportions of different categories of interruptions depended on the source and the target

-The degree of interference for the same category of interruption was not identical from one group to another

-The surgical group was the most often targeted by interruptions. 


\section{Factors related to interruptions}

The occurrence of interruptions was mainly dependent on the following factors:

-Team familiarity, referring to a group of people used to working together, sharing a similar mental model. "Mental models can be defined as knowledge structures which allow individuals to describe, explain and predict events in their environment”. ${ }^{2}$ Sharing mental models allows a team to work efficiently and to adapt quickly to a situation. ${ }^{62}$ It has been demonstrated that a high level of familiarity decreases the number of interruptions, ${ }^{28,36,49}$ improves the performance of the surgical team by decreasing the duration of the surgical procedure ${ }^{63}$ and postoperative complications, ${ }^{64}$ and by promoting teamwork and communication. ${ }^{65}$

-Technology. Interruptions related to equipment problems represented the highest risk of significant impact on the surgical procedure. ${ }^{26,29-31,33,52,55-57}$ Thus, a surgical procedure requiring many technological tools would be more likely to be exposed to interruptions responsible for serious interference.

•Expertise. This aspect was studied in experimental simulation studies comparing experts and novices during the performance of an interrupted task. These studies showed that experts were superior to novices in terms of accuracy in performing the secondary task $^{39,41,46}$ and in speed of execution. ${ }^{46}$ One observational study carried out in the OR concluded that expertise of the dyad surgeon/scrub nurse decreased the length of interruptions. ${ }^{36}$

\section{Impact of interruptions}

Interruptions altered quality and safety in the OR. Wiegmann et al. ${ }^{24}$ showed a correlation between interruptions and errors during 31 cardiothoracic surgeries. Several studies contribute to explaining this correlation. Wheelock et al. showed that interruptions were correlated with higher stress of the surgical team in 90 general surgeries. ${ }^{31}$ Weber et al. 
reported that interruptions were associated with higher workload and stress in 40 roboticassisted prostatectomies and Weigl et al. reported a correlation between interruptions and a higher workload in 56 general and orthopedic surgeries. ${ }^{30,33}$ Sevdalis et al. showed that intraoperative distracting communications were associated with deterioration of the use of a safety checklist in 19 urological surgeries. ${ }^{27}$ Healey et al. showed a relationship between better teamwork (measured by the Observational Teamwork Assessment for Surgery (OTAS)) and lower intraoperative interference of interruptions. ${ }^{52}$

On the contrary, Allers et al. did not find a correlation between interruptions and workload, ${ }^{32}$ Yoong et al. reported the absence of correlation between interruptions and surgical complications. $^{35}$

Several experimental studies in simulated environments were conducted. ${ }^{37-47}$ These studies showed that both rate of errors and time of completion increased when the surgeons were interrupted during the main task accomplishment and the secondary task. Performance deterioration was greater for novices than for experienced surgeons. One study demonstrated a positive aspect of coping with interruptions during learning. ${ }^{37}$ It compared the performance of two groups of novices after learning a surgical procedure on a simulator in the presence or absence of interruptions (noise and visual distraction). This study showed that the group trained in the interrupted condition was more efficient than the group trained without interruption when they were compared in real conditions.

\section{Discussion}

\section{Observation and impact of interruptions}

There were two main methodological approaches identified in this review. The first one was observational in a natural environment. This approach showed that interruptions were commonly observed in the OR and in various specialties, the frequency of interruptions ranged from $2.4 / \mathrm{h}$ to $114 / \mathrm{h}$. The classification of interruptions and their severity differed from 
one study to another as mentioned in the results section. This heterogeneity made it difficult to compare studies. However, similar categories of interruptions were most frequently observed, the results being comparable from one study to another. These observational studies made it possible to define an image of the most frequent interruptions (such as communication issues or distractions) and of the most severe (such as equipment or procedural issues). Several studies carried out in a natural environment evaluated the impact of interruptions on the quality and safety of surgical procedures. Some studies showed that interruptions increased the workload, ${ }^{30,33}$ stress $^{31}$ or risk of errors. ${ }^{24}$ However, other studies found no correlation between interruptions and workload or complications. ${ }^{32,35}$ Several factors were also found to have an impact on interruptions: team familiarity which reduces numbers of interruptions and promotes team work and communication, ${ }^{28,36,49,66}$ expertise which reduces the frequency of interruptions. $^{36}$

The second methodological approach was experimental in a simulated environment. These studies enabled comparison of performance of surgeons in an interrupted situation with those in a non-interrupted situation (control group). This approach made it possible to measure the impact of interruptions more precisely than those realized in a natural environment. It demonstrated a negative impact of interruptions with an increase in error rates and time of task completion. ${ }^{37-47}$ A study carried out in a simulated environment demonstrated a potential beneficial effect of interruptions in the context of surgery learning, with better surgical performance of trainees who had been trained in simulated programs with interruptions. $^{37}$

\section{Quality appraisal and limitations of included studies}

We used a quality assessment tool to evaluate the quality of the included studies. This tool was useful even though it was initially designed for observational cohort and crosssectional studies. It allowed us to evaluate key methodological points for each study. We 
observed several important methodological limitations. First, studies frequently included a limited number of procedures, as detailed in Table A, which is a strong limitation when statistical analysis is carried out for comparisons between groups. Second, there were no sample size justification, which is a limitation when the objective is to observe a significant statistical difference between groups. Third, data (interruptions) were extracted by observers from live surgical procedures. The surgical team, being observed, may be led to modify their behavior and cause distortion of the observation. Finally, observational studies were heterogeneous as regards the type of surgical settings and the definition of interruptions. It follows that results of observational study in one particular OR can hardly be generalized to other OR.

\section{Propositions for future research}

Studies conducted in a real operating room are valuable in order to assess the actual impact of interruptions on a trained team. However, many confounding factors should be measured to reduce the risk of misinterpretation. A solution could be to perform prospective studies with a control group, which would make it possible to assess more precisely the impact of interruptions on the surgical procedure with measurement of team familiarity and expertise. The study of the timing of interruptions during the surgical procedure should also be further studied as it was only examined in three studies. ${ }^{26,35,54}$ This question is of importance, as it could lead to specific education of the OR team about phases of the surgical procedure which should not be interrupted (during the closing phase when the count is made by the OR nurses for example).

From an educational point of view, as interruptions are frequently seen in real environments, the development of simulated training programs would certainly be more effective if it included interruptions or settings corresponding to a real OR environment (OR noise, various interruptions). ${ }^{37}$ 
Last but not least, our review showed that no study has specifically evaluated the potential positive aspect of interruptions in surgery. In the work psychology literature, some interruptions were found to have potentially beneficial effect on workers. ${ }^{6,7,13}$ We suggest that future research should be done to explore this point. As we learn from the data of work psychology research, potential beneficial interruptions may exist in the OR: contradictions (another surgeon interrupts a colleague and gives advice on the surgical case), breaks and some distractions (alarms which alert the teams to potentially serious problem, music or caseirrelevant communication which could promote team bonding and decrease workload). Thus, we can hypothesize that some interruptions could have a beneficial impact on the care process in the OR by permitting information exchange within the surgical team but also with external members, and by promoting the well-being of the OR team.

\section{Conclusions}

Interruptions during a surgical procedure are diverse and several classifications have been used in the literature. Interruptions are probably risk factors for errors in the OR but the evidence of the link between their number and these errors is not clear. The concept of interruption of surgical procedures needs to be defined more precisely: potentially beneficial interruptions must be separated from those that have a negative impact. This approach could make it possible to target only negative interruptions which should be reduced by safeguards, and leave aside those with no potential consequences.

\section{Disclosure}

The authors report no proprietary or commercial interest in any product mentioned or concept discussed in this article.

This research did not receive any specific grant from funding agencies in the public, commercial, or not-for-profit sectors. 


\section{Acknowledgements}

The authors thank Deirdre McKeown for revising the English style.

\section{References}

1.Institute of Medicine (US) Committee on quality of health care in America. To err is human: building a safer health system. In: Kohn LT, Corrigan JM, Donaldson MS, eds. Washington, DC: National Academies Press; 2000.

2. Gawande AA, Thomas EJ, Zinner MJ, Brennan TA. The incidence and nature of surgical adverse events in Colorado and Utah in 1992. Surgery. 1999;126:66-75.

3.Etchells E, O’Neill C, Bernstein M. Patient safety in surgery: error detection and prevention. World J Surg. 2003;27:936-941.

4. Shouhed D, Gewertz B, Wiegmann D, Catchpole K. Integrating human factors research and surgery: a review. Arch Surg. 2012;147:1141-1146.

5. Li SYW, Magrabi F, Coiera E. A systematic review of the psychological literature on interruption and its patient safety implications. J Am Med Inform Assoc. 2012;19:6-12. 6. Jett QR, George JM. Work interrupted: a closer look at the role of interruptions in organizational life. Acad Manage Rev. 2003;28:494.

7. Trafton JG, Monk CA. Task Interruptions. Rev Hum Factors Ergon. 2007;3:111-126.

8. Wilson MR, Poolton JM, Malhotra N, Ngo K, Bright E, Masters RSW. Development and validation of a surgical workload measure: The Surgery Task Load Index (SURG-TLX). World J Surg. 2011;35:1961-1969.

9. Yu D, Lowndes B, Thiels C, Bingener J, Abdelrahman A, Lyons R, et al. Quantifying intraoperative workloads across the surgical team roles: room for better balance? World $J$ Surg. 2016;40:1565-1574. 
10. Arora S, Sevdalis N, Nestel D, Woloshynowych M, Darzi A, Kneebone R. The impact of stress on surgical performance: A systematic review of the literature. Surgery. 2010;147:318330.

11. Yull S, Flin R, Paterson-Brown S, Maran N. Non-technical skills for surgeons in the operating room: a review of the literature. Surgery. 2006;139:140-149.

12. Foroughi CK, Werner NE, Nelson ET, Boehm-Davis DA. Do interruptions affect the quality of work? Proc Hum Factors Ergon Soc Annu Meet. 2013;57:154-157.

13. Keus van de Poll M, Sörqvist P. Effects of task interruption and background speech on word processed writing: effects on writing performance. Appl Cogn Psychol. 2016;30:430439.

14. Zijlstra FR, Roe RA, Leonora AB, Krediet I. Temporal factors in mental work: Effects of interrupted activities. J Occup Organ Psychol. 1999;72:163-185.

15. Eyrolle H, Cellier J-M. The effects of interruptions in work activity: Field and laboratory results. Appl Ergon. 2000;31:537-543.

16. Furnham A, Strbac L. Music is as distracting as noise: the differential distraction of background music and noise on the cognitive test performance of introverts and extraverts. Ergonomics. 2002;45:203-217.

17. Gillie T, Broadbent D. What makes interruptions disruptive? A study of length, similarity, and complexity. Psychol Res. 1989;50:243-250.

18. Trafton JG, Altmann EM, Brock DP, Mintz FE. Preparing to resume an interrupted task: effects of prospective goal encoding and retrospective rehearsal. Int J Hum Comput Stud. 2003;58:583-603.

19. Li SYW, Magrabi F, Coiera E. A systematic review of the psychological literature on interruption and its patient safety implications. J Am Med Inform Assoc. 2012;19:6-12. 
20. Mentis HM, Chellali A, Manser K, Cao CGL, Schwaitzberg SD. A systematic review of the effect of distraction on surgeon performance: directions for operating room policy and surgical training. Surg Endosc. 2016;30:1713-1724.

21. https://www.nhlbi.nih.gov/health-topics/study-quality-assessment-tools

22. Zheng B, Martinec DV, Cassera MA, Swanström LL. A quantitative study of disruption in the operating room during laparoscopic antireflux surgery. Surg Endosc. 2008;22:2171-2177.

23. Lingard L. Communication failures in the operating room: an observational classification of recurrent types and effects. Qual Saf Health Care. 2004;13:330-334.

24. Wiegmann DA, ElBardissi AW, Dearani JA, Daly RC, Sundt TM. Disruptions in surgical flow and their relationship to surgical errors: An exploratory investigation. Surgery. 2007;142:658-665.

25. Sevdalis N, Healey AN, Vincent CA. Distracting communications in the operating theatre. J Eval Clin Pract. 2007;13:390-394.

26. Antoniadis S, Passauer-Baierl S, Baschnegger H, Weigl M. Identification and interference of intraoperative distractions and interruptions in operating rooms. J Surg Res. 2014;188:2129.

27. Sevdalis N, Undre S, McDermott J, Giddie J, Diner L, Smith G. Impact of intraoperative distractions on patient safety: a prospective descriptive study using validated instruments. World J Surg. 2014;38:751-758.

28. Gillespie BM, Chaboyer W, Fairweather N. Interruptions and miscommunications in surgery: an observational study. AORN J. 2012;95:576-590.

29. Persoon MC, Broos HJHP, Witjes JA, Hendrikx AJM, Scherpbier AJJM. The effect of distractions in the operating room during endourological procedures. Surg Endosc. 2011;25:437-443.

30. Weigl M, Antoniadis S, Chiapponi C, Bruns C, Sevdalis N. The impact of intra-operative 
interruptions on surgeons’ perceived workload: an observational study in elective general and orthopedic surgery. Surg Endosc. 2015;29:145-153.

31. Wheelock A, Suliman A, Wharton R, Babu ED, Hull L, Vincent C, et al. The impact of operating room distractions on stress, workload, and teamwork. Ann Surg. 2015;261:10791084.

32. Allers JC, Hussein AA, Ahmad N, Cavuoto L, Wing JF, Hayes RM, et al. Evaluation and impact of workflow interruptions during robot-assisted surgery. Urology. 2016;92:33-37.

33. Weber J, Catchpole K, Becker AJ, Schlenker B, Weigl M. Effects of flow disruptions on mental workload and surgical performance in robotic-assisted surgery. World J Surg. 2018;42:3599-3607.

34. Willett M, Gillman O, Shin E, Sewart E, Muller D, Nauta M, et al. The impact of distractions and interruptions during Cesarean Sections: a prospective study in a London teaching hospital. Arch Gynecol Obstet. 2018;298:313-318.

35. Yoong W, Khin A, Ramlal N, Loabile B, Forman S. Interruptions and distractions in the gynaecological operating theatre: irritating or dangerous? Ergonomics. 2015;58:1314-1319.

36. Henaux PL, Michinov E, Rochat J, Hemon B, Jannin P, Riffaud L. Relationships between expertise, crew familiarity and surgical workflow disruptions: an observational study. World $J$ Surg. 2018;43:431-438.

37. Szafranski C, Kahol K, Ghaemmaghami V, Smith M, Ferrara JJ. Distractions and surgical proficiency: an educational perspective. Am J Surg. 2009;198:804-810.

38. Pluyter JR, Buzink SN, Rutkowski A-F, Jakimowicz JJ. Do absorption and realistic distraction influence performance of component task surgical procedure? Surg Endosc. 2010;24:902-907.

39. Park J, Waqar S, Kersey T, Modi N, Ong C, Sleep T. Effect of distraction on simulated anterior segment surgical performance. J Cataract Refract Surg. 2011;37:1517-1522. 
40. Goodell KH, Cao CG, Schwaitzberg SD. Effects of cognitive distraction on performance of laparoscopic surgical tasks. J Laparoendosc Adv Surg Tech A. 2006;16:94-98.

41. Hsu KE, Man F-Y, Gizicki RA, Feldman LS, Fried GM. Experienced surgeons can do more than one thing at a time: effect of distraction on performance of a simple laparoscopic and cognitive task by experienced and novice surgeons. Surg Endosc. 2008;22:196-201. 42. Weigl M, Stefan P, Abhari K, Wucherer P, Fallavollita P, Lazarovici M, et al. Intraoperative disruptions, surgeon's mental workload, and technical performance in a full-scale simulated procedure. Surg Endosc. 2016;30:559-566.

43. Moorthy K, Munz Y, Undre S, Darzi A. Objective evaluation of the effect of noise on the performance of a complex laparoscopic task. Surgery. 2004;136:25-30.

44. Miskovic D, Rosenthal R, Zingg U, Oertli D, Metzger U, Jancke L. Randomized controlled trial investigating the effect of music on the virtual reality laparoscopic learning performance of novice surgeons. Surg Endosc. 2008;22:2416-2420.

45. Feuerbacher RL, Funk KH, Spight DH, Diggs BS, Hunter JG. Realistic distractions and interruptions that impair simulated surgical performance by novice surgeons. Arch Surg. 2012;147:1026-1030.

46. Suh IH, Chien J-H, Mukherjee M, Park S-H, Oleynikov D, Siu K-C. The negative effect of distraction on performance of robot-assisted surgical skills in medical students and residents. Int J Med Robot. 2010;6:377-381.

47. Zheng B, Martinec DV, Cassera MA, Swanström LL. A quantitative study of disruption in the operating room during laparoscopic antireflux surgery. Surg Endosc. 2008;22:2171-2177. 48. Murji A, Luketic L, Sobel ML, Kulasegaram KM, Leyland N, Posner G. Evaluating the effect of distractions in the operating room on clinical decision-making and patient safety. Surg Endosc. 2016;30:4499-4504.

49. Allers JC, Hussein AA, Ahmad N, Cavuoto L, Wing JF, Hayes RM, et al. Evaluation and 
impact of workflow interruptions during robot-assisted surgery. Urology. 2016;92:33-37.

50. Sujka JA, Safcsak K, Bhullar IS, Havron WS $3^{\text {rd }}$. Simulation-based testing of pager interruptions during laparoscopic cholecystectomy. J Surg Educ. 2018;75:1351-1356.

51. Persoon MC, van Putten K, Muijtjens AM, Witjes JA, Hendrikx AJ, Scherpbier AJ. Effect of distraction on the performance of endourological tasks: a randomized controlled trial. $B J U$ Int. 2011;107:1653-1657.

52. Healey AN, Olsen S, Davis R, Vincent CA. A method for measuring work interference in surgical teams. Cogn Tech Work. 2008;10:305-312.

53. Sevdalis N, Forrest D, Undre S, Darzi A, Vincent C. Annoyances, disruptions, and interruptions in surgery: the disruptions in surgery index (DiSI). World J Surg. 2008;32:16431650.

54. Morgan L, Robertson E, Hadi M, Catchpole K, Pickering S, New S, et al. Capturing intraoperative process deviations using a direct observational approach: the glitch method. BMJ open. 2013;3:e003519.

55. Parker SEH, Laviana AA, Wadhera RK, Wiegmann DA, Sundt TM. Development and evaluation of an observational tool for assessing surgical flow disruptions and their impact on surgical performance. World J Surg. 2010;34:353-361.

56. Healey AN, Sevdalis N, Vincent CA. Measuring intra-operative interference from distraction and interruption observed in the operating theatre. Ergonomics. 2006;49:589-604.

57. Healey AN, Primus CP, Koutantji M. Quantifying distraction and interruption in urological surgery. Qual Saf Health Care. 2007;16:135-139.

58. Seelandt JC, Tschan F, Keller S, Beldi G, Jenni N, Kurmann A, et al. Assessing distractors and teamwork during surgery: developing an event-based method for direct observation. BMJ Qual Saf. 2014;23:918-929.

59. Lee JY, Lantz AG, McDougall EM, Landman J, Gettman M, Sweet R, et al. Evaluation of 
potential distractors in the urology operating room. J Endourol. 2013;27:1161-1165.

60. Elfering A, Nützi M, Koch P, Baur H. Workflow interruptions and failed action regulation in surgery personnel. Saf Health Work. 2014;5:1-6.

61. Wright MI. Implementing no interruption zones in the perioperative environment. AORN J. 2016;104:536-540.

62. Mathieu JE, Heffner TS, Goodwin GF, Salas E, Cannon-Bowers JA. The influence of shared mental models on team process and performance. J Appl Psychol. 2000;85:273-283. 63. ElBardissi AW, Duclos A, Rawn JD, Orgill DP, Carty MJ. Cumulative team experience matters more than individual surgeon experience in cardiac surgery. J Thorac Cardiovasc Surg. 2013;145:328-333.

64. Kurmann A, Keller S, Tschan-Semmer F, Seelandt J, Semmer NK, Candinas D, et al. Impact of team familiarity in the operating room on surgical complications. World J Surg. 2014;38:3047-3052.

65. Maruthappu M, Duclos A, Zhou CD, Lipsitz SR, Wright J, Orgill D, et al. The impact of team familiarity and surgical experience on operative efficiency: a retrospective analysis. $J R$ Soc Med. 2016;109:147-153.

66. Hart SG. Nasa-Task Load Index (NASA-TLX); 20 Years Later. Proc Hum Factors Ergon Soc Annu Meet. 2006;50:904-908.

67. Hull L, Arora S, Kassab E, Kneebone R, Sevdalis N. Observational teamwork assessment for surgery: content validation and tool refinement. J Am Coll Surg. 2011;212:234-243.

68. Marteau TM, Bekker H. The development of a six-item short-form of the state scale of the Spielberger State-Trait Anxiety Inventory (STAI). Br J Clin Psychol. 1992;31:301-306. 
Fig. A Flow diagram of the literature search

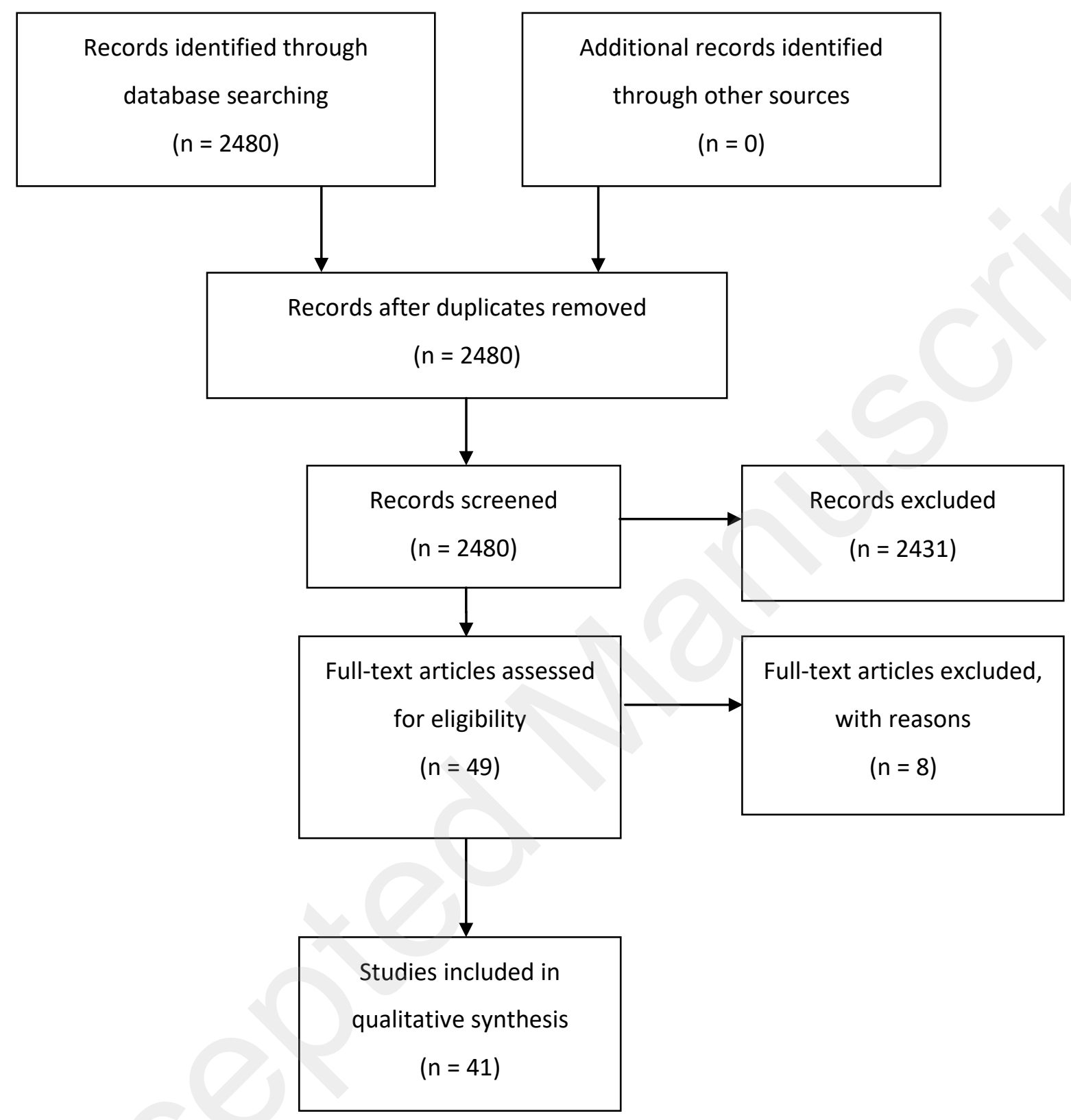


Tables 
Table A Overview of observational studies in the operating room

\begin{tabular}{|c|c|c|c|c|}
\hline Authors & $\begin{array}{c}\text { Quality } \\
\text { Assessment }^{21}\end{array}$ & Type and objective of the study & Classification(s) used & Main results \\
\hline Allers et al. $^{32}$ & Fair & $\begin{array}{l}\text { Observation of } 10 \text { robot assisted radical prostatectomies } \\
\text { Observation of interruptions and relations with team } \\
\text { familiarity and workload }\end{array}$ & $\begin{array}{l}\text { Classification of interruptions } \\
\text { Equipment/technology } \\
\text { Supervision/training } \\
\text { Procedure specific } \\
\text { Procedure unrelated } \\
\text { Team familiarity score } \\
\text { Workload measured by NASA } \text { TLX }^{66}\end{array}$ & $\begin{array}{l}\text { No correlation between interruptions and workload } \\
\text { Negative correlation between interruptions and team } \\
\text { familiarity } \\
\text { Categories of interruptions } \\
\text { Equipment/technology: } 56 \% \\
\text { Supervision/training: } 29 \%\end{array}$ \\
\hline $\begin{array}{l}\text { Antoniadis et } \\
\text { al. }^{26}\end{array}$ & Good & $\begin{array}{l}\text { Observation of } 65 \text { abdominal and orthopaedic surgeries } \\
\text { Observation of interruption and degree of interference of } \\
\text { interruptions on the surgical team }\end{array}$ & $\begin{array}{l}\text { Classification of interruptions } \\
\text { People entering or exiting the OR } \\
\text { Phone or beeper calls } \\
\text { Radio-related distraction (e.g., radio too loud or noisy) } \\
\text { CIC by surgeons } \\
\text { CIC by anaesthetists } \\
\text { CIC by nurses } \\
\text { CIC by external personnel } \\
\text { Equipment (missing or non-functioning provisions) } \\
\text { Work environment } \\
\text { Procedural (distractions intrinsic to surgical work) } \\
\text { Movement in front of or behind laparoscopic monitors (applicable during laparoscopic procedures) } \\
\text { Interference of interruptions } \\
\text { Nine-point ordinal scale (table B) }\end{array}$ & $\begin{array}{l}9.82 \text { interruptions per hour } \\
\text { Categories of interruptions } \\
\text { People entering or exiting the OR: } 31 \% \\
\text { Phone or beeper calls: } 23 \% \\
\text { Procedural: } 10 \% \\
\text { CIC by surgeons: } 9 \% \\
\text { Equipment failure: } 8 \% \\
\text { CIC by anaesthetist: } 6 \% \\
\text { Work environment: } 6 \% \\
\text { CIC by nurse: } 4 \% \\
\text { Interference rating } \\
\text { Equipment failure: } 7 \\
\text { Work environment: } 6 \\
\text { Phone or beeper: } 4 \\
\text { People entering or exiting the OR: } 3\end{array}$ \\
\hline $\begin{array}{ll}\text { Healey } & \text { et } \\
\text { al. }^{56} & \end{array}$ & Good & $\begin{array}{l}\text { Observation of } 50 \text { general surgeries } \\
\text { Observation of interruptions and degree of interference of } \\
\text { interruptions on the surgical team }\end{array}$ & $\begin{array}{l}\text { Classification of interruptions } \\
\text { Phone } \\
\text { Beeper } \\
\text { Radio } \\
\text { CIC } \\
\text { Communication difficulties } \\
\text { External staff } \\
\text { Equipment } \\
\text { Work environment } \\
\text { Procedural } \\
\text { Movement in front of or behind monitors (laparoscopic cases only) } \\
\text { Interference of interruptions } \\
\text { Nine-point ordinal scale (table B) }\end{array}$ & $\begin{array}{l}17 \text { interruptions per hour } \\
\text { Categories of interruptions } \\
\text { Most frequent: movement in front of or behind the video } \\
\text { monitor during laparoscopic operations and beeper } \\
\text { Less frequent: radio and communication difficulties } \\
\text { High interference categories } \\
\text { Equipment, procedure } \\
\text { Environment, external staff, beeper, CIC of the surgeon }\end{array}$ \\
\hline $\begin{array}{ll}\text { Healey } & \text { et } \\
\text { al. }{ }^{52} & \end{array}$ & Fair & $\begin{array}{l}\text { Observation of } 22 \text { laparoscopic cholecystectomies } \\
\text { Assessment of teamwork, interruptions and degree of } \\
\text { interference of interruptions on the surgical team }\end{array}$ & $\begin{array}{l}\text { Classification of interruptions } \\
\text { Idem Healey et al. }{ }^{56} \\
\text { Interference of interruptions }\end{array}$ & $\begin{array}{l}23 \text { interruptions per hour } \\
\text { Categories of interruptions } \\
\text { Equipment, work environment, procedure: } 38 \%\end{array}$ \\
\hline
\end{tabular}


Nine-point ordinal scale (table B)

Teamwork measured by Observational Teamwork Assessment for Surgery (OTAS) ${ }^{67}$
Movement in front of or behind monitor: $23 \%$

CIC: $15 \%$

External staff interruption: $13 \%$

Other: $<5 \%$

High interference categories

Equipment, environment, procedure

27 interruptions per hour

Classification of interruptions

Observation of interruptions and degree of interference of Conversation

interruptions on the surgical team Phone

Evaluate noise in the OR

\section{Beeper}

Equipment

Procedure

Environment

Monitor

Interference of interruptions

Eight-point ordinal scale

\section{Categories of interruptions}

Conversation: $32 \%$

Environment: $27 \%$

Phone: $21 \%$

Equipment: $9 \%$

Other: $<5 \%$

Interference rating

Equipment: 7

Procedure: 5
Conversation: 5

Other: between 1 et 3

\section{Classification of interruptions}

Observation of 12 neurosurgical procedures

Evaluate the relationship between interruptions, team Communication

familiarity and expertise

Coordination

Equipment

Interruptions by colleagues

Phone/alarm

Distractions

Miscommunications were defined as an exchange during which information was either inconplece or

\begin{tabular}{llll}
\hline Gillespie & et & Fair & Observation of 160 various surgical cases
\end{tabular}

Observation of interruptions and miscommunications

content, experience

Interruptions: procedural or conversational

$9.9 \%$ of the duration of the surgical procedures concerned

an interruption

Team familiarity decreased interruptions

Expertise decreased interruptions

Categories of interruptions

Distraction: $29.7 \%$

Interruptions by colleagues: $25.2 \%$

Communication: $10.3 \%$

Miscommunications occurred in $57 \%$ of cases $(1.9$ per

Experience: 31\% ; Occasion: 26\% ; Content: 20\% ; Purpose: $13 \%$; Audience: $10 \%$

Interruptions occurred in $67 \%$ of cases (2.3 per case)

Conversational interruptions: 69\%; Procedural interruptions: $66 \%$

Type of communication failure

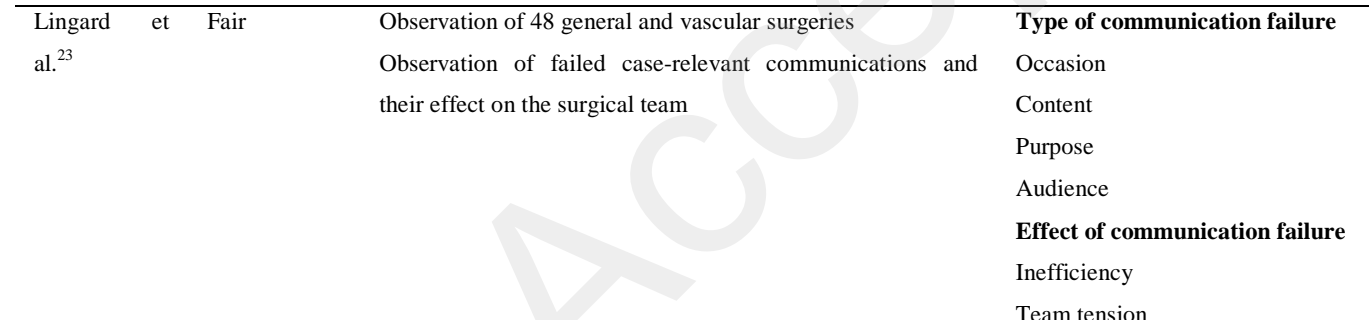

\section{Type}

Occasion: $46 \%$

Content: $36 \%$

Purpose: $24 \%$

Audience: $21 \%$

Effect

No visible immediate effect: $64 \%$ 


\begin{tabular}{|c|c|c|c|}
\hline & & $\begin{array}{l}\text { Delay } \\
\text { Workaround } \\
\text { Resource waste } \\
\text { Patient inconvenience } \\
\text { Procedural error }\end{array}$ & $\begin{array}{l}\text { Inefficiency: } 18 \% \\
\text { Team tension: } 12 \% \\
\text { Delay: } 8 \% \\
\text { Workaround: } 2 \% \\
\text { Resource waste: } 2 \% \\
\text { Patient inconvenience: } 2 \% \\
\text { Procedural error: } 1 \% \\
\end{array}$ \\
\hline $\begin{array}{lll}\text { Morgan } & \text { et } & \text { Good } \\
\text { al. }^{54} & & \end{array}$ & $\begin{array}{l}\text { Observation of } 429 \text { various surgical cases } \\
\text { Validation of a classification of interruptions }\end{array}$ & $\begin{array}{l}\text { Classification of interruptions } \\
\text { (glitch categories) } \\
\text { Absence } \\
\text { Communication } \\
\text { Distractions } \\
\text { Environment } \\
\text { Equipment design } \\
\text { Maintenance } \\
\text { Health and safety } \\
\text { Planning and preparation } \\
\text { Patient related } \\
\text { Process deviation } \\
\text { Slips } \\
\text { Training } \\
\text { Workspace }\end{array}$ & $\begin{array}{l}\text { Interruptions varied from } 0 \text { to } 83 \text { (mean } 14 \text { per case) } \\
7-8 \text { interruptions per hour } \\
\text { Categories of interruptions } \\
\text { Distraction: } 23 \% \\
\text { Planning and preparation: } 14 \% \\
\text { Process deviation: } 11 \% \\
\text { Equipment design: } 10 \%\end{array}$ \\
\hline Parker et al. ${ }^{55} \quad$ Fair & $\begin{array}{l}\text { Observation of } 10 \text { cardiothoracic surgeries } \\
\text { Development and validation of a method of measure of } \\
\text { interruptions in surgery }\end{array}$ & $\begin{array}{l}\text { Classification of interruptions } \\
\text { Technical factors } \\
\text { Environmental factors } \\
\text { Technology and instruments } \\
\text { Training and procedure } \\
\text { Teamwork } \\
\text { Other } \\
\text { Interference of interruptions } \\
\text { six-point ordinal scale }\end{array}$ & $\begin{array}{l}7.1 \text { interruptions per hour } \\
\text { Most frequent but least interfering categories: } \\
\text { Phone and beeper interruptions } \\
\text { Least frequent but most interfering categories: } \\
\text { Technology and instruments, technical factors }\end{array}$ \\
\hline $\begin{array}{lll}\begin{array}{l}\text { Persoon } \\
\text { al. }\end{array}{ }^{29} & \text { et } & \text { Fair } \\
\end{array}$ & $\begin{array}{l}\text { Observation of } 78 \text { urological surgeries } \\
\text { Observation of interruptions and degree of interference of } \\
\text { interruptions on the surgical team }\end{array}$ & $\begin{array}{l}\text { Classification of interruptions } \\
\text { Pager } \\
\text { Telephone } \\
\text { Radio } \\
\text { Door movement } \\
\text { Equipment } \\
\text { Procedure } \\
\text { Patient-irrelevant communication } \\
\text { Medically-irrelevant communication } \\
\text { Interference of interruptions }\end{array}$ & $\begin{array}{l}33 \text { interruptions per hour } \\
\text { Categories of interruptions } \\
\text { Door movement: } 44 \% \\
\text { Radio: } 13 \% \\
\text { Medically-irrelevant communication: } 11 \% \\
\text { Other: }<10 \% \\
\text { Interference rating } \\
\text { Equipment, procedure-related communication, patient- } \\
\text { irrelevant communication, and medically } \\
\text { irrelevant communication: between } 4 \text { and } 5\end{array}$ \\
\hline
\end{tabular}




\begin{tabular}{|c|c|c|c|c|}
\hline $\begin{array}{ll}\text { Sevdalis } & \text { et } \\
\text { al. }^{25} & \end{array}$ & Fair & $\begin{array}{l}\text { Observation of } 48 \text { general surgeries } \\
\text { Observation of CIC and their interference on surgical team }\end{array}$ & $\begin{array}{l}\text { Interference of interruptions } \\
\text { nine-point ordinal scale }\end{array}$ & $\begin{array}{l}167 \text { CIC observed, } 3.5 \text { per case } \\
\text { Frequency per time unavailable } \\
\text { Categories of CIC } \\
\text { Irrelevant comment/query by team staff: } 27 \% \\
\text { Irrelevant comment/query by external staff: } 17 \% \\
\text { Next patient: } 13 \% \\
\text { Other patient/list: } 9 \% \\
\text { Teaching: } 9 \% \\
\text { Equipment/provisions: } 9 \% \\
\text { Interference rating } \\
\text { Equipment/provisions: highest rating }\end{array}$ \\
\hline $\begin{array}{ll}\text { Sevdalis } & \text { et } \\
\text { al. }^{27} & \end{array}$ & Fair & $\begin{array}{l}\text { Observation of } 19 \text { urological surgeries } \\
\text { Observation of interruptions and degree of interference of } \\
\text { interruptions on the surgical team }\end{array}$ & $\begin{array}{l}\text { Classification of interruptions } \\
\text { Distracting communications } \\
\text { Phones/pagers } \\
\text { Equipment/provisions } \\
\text { OR environment } \\
\text { Distractions caused by other departments } \\
\text { Distractions caused by a team member } \\
\text { Teaching } \\
\text { Interference of interruptions } \\
\text { Nine-point ordinal scale } \\
\text { Urologic patient safety checklist: Patient tasks, equipment tasks, communication tasks }\end{array}$ & $\begin{array}{l}6 \text { interruptions per hour } \\
\text { Categories of interruptions } \\
\text { Distracting communications: } 63 \% \\
\text { Equipment/provisions: } 25 \% \\
\text { "more intraoperative distracting communications were } \\
\text { associated } \\
\text { with deterioration of patient safety checks" }\end{array}$ \\
\hline Weber et al. ${ }^{33}$ & Good & $\begin{array}{l}\text { Observation of } 40 \text { robotic assisted radical prostatectomies } \\
\text { Impact of interruptions on workload and performance }\end{array}$ & $\begin{array}{l}\text { Classification of interruptions } \\
\text { CRC } \\
\text { CIC } \\
\text { Coordination } \\
\text { People entering the OR } \\
\text { Phone/beeper } \\
\text { Training } \\
\text { Equipment } \\
\text { Environment } \\
\text { Patient factors } \\
\text { Procedural }\end{array}$ & $\begin{array}{l}15.8 \text { interruptions per hour } \\
\text { Most frequent categories of interruptions } \\
\text { CIC, people entering the OR, procedural } \\
\text { Highest interference rating } \\
\text { Equipment, instrument change } \\
\text { Lowest interference rating } \\
\text { people entering the OR, phone/beeper }\end{array}$ \\
\hline
\end{tabular}


Nine-point ordinal scale

Workload measured by Surgery Task Load Index ${ }^{8}$

Performance measured by 2 questions

How productive have you been in your work during the operation?

How do you evaluate the quality of your work during the operation?

Observation of interruptions and degree of interference of People entering/exiting the OR

interruptions on the surgical team

Phone/beeper/radio

Impact of interruptions and workload

CIC

Equipment

Movement in front or behind monitors

Work environment

Procedural

Interference of interruptions

Nine-point ordinal scale

Workload measured by Surgery Task Load Index ${ }^{8}$

\section{Classification of interruptions}

Observation of 90 general surgeries

Observation of interruptions and their impact on workload,

stress and teamwork

External staff entering, exiting or initiating CIC

CIC within the OR team

Acoustic (telephone, mobile phones, pagers, radio, and external noises)

Equipment

Work environment

Interference of interruptions

Nine-point ordinal scale

Workload measured by NASA Task Load Index ${ }^{66}$

Stress measured by State-Trait Anxiety Inventory ${ }^{68}$

Teamwork measured by Observational Teamwork Assessment for Surgery (OTAS) ${ }^{67}$
9.8 interruptions per hour

Categories of interruptions

People entering/exiting the OR: $31 \%$

Telephone/beeper: 24\%

Case-irrelevant communication: 21\%

Equipment, movement, environment: 15\%

Procedural: $10 \%$

Interference rating

Equipment, movement, environment: 6

Procedural: 5

Case-irrelevant communication: 5

Telephone/beeper: 4

People entering/exiting the OR: 3

Interruptions seemed to be correlated with a higher workload

6.7 interruptions per hour

Most frequent categories of interruptions

External staff

CIC

Highest interference rating

Equipment

Procedural

Frequency of interruptions was correlated with higher stress 


\begin{tabular}{|c|c|c|c|c|}
\hline $\begin{array}{l}\text { Wiegmann et } \\
\text { al. }^{24}\end{array}$ & Fair & $\begin{array}{l}\text { Observation of } 31 \text { cardiothoracic surgeries } \\
\text { Evaluation of the correlation between interruptions and } \\
\text { surgical errors }\end{array}$ & $\begin{array}{l}\text { Classification of interruptions } \\
\text { Teamwork } \\
\text { Extraneous interruptions } \\
\text { Equipment and technology } \\
\text { Resource-based issues } \\
\text { Supervisory/training-related issues }\end{array}$ & $\begin{array}{l}.7 \text { errors per hour } \\
8 \text { interruptions per hour } \\
\text { Categories of interruptions } \\
\text { Teamwork: } 52 \% \\
\text { Extraneous interruptions: } 17 \% \\
\text { Supervisory/training issues: } 12 \% \\
\text { Equipment and technology: } 11 \% \\
\text { Resource-based issues: } 8 \% \\
\text { Frequency of interruptions was correlated with } \\
\text { surgical errors }\end{array}$ \\
\hline $\begin{array}{ll}\text { Willett } & \text { et } \\
\text { al. }^{34} & \end{array}$ & Fair & $\begin{array}{l}\text { Observation of } 56 \text { cesarean sections } \\
\text { Observation of interruptions and their impact on } \\
\text { perioperative complications }\end{array}$ & $\begin{array}{l}\text { Classification of interruptions } \\
\text { CIC } \\
\text { Phone/bleep } \\
\text { Theatre traffic } \\
\text { Baby crying } \\
\text { Equipment } \\
\text { Other } \\
\text { Interference of interruptions } \\
\text { Level I: minimal level of distraction } \\
\text { Level II: one member distracted } \\
\text { Level III: more than one member distracted }\end{array}$ & $\begin{array}{l}\text { No perioperative complications occurred } \\
\text { Categories of interruptions } \\
\text { CIC: } 36 \% \\
\text { Theatre traffic: } 23 \% \\
\text { Equipment: } 11.6 \% \\
\text { Other: }<10 \% \\
\text { Mean number of level II/III interruptions } \\
13.20 \text { per case } \\
\text { Higher in case of elective compared to emergency } \\
\text { procedures (14.9 versus } 12.0)\end{array}$ \\
\hline Yoong et al. ${ }^{35}$ & Fair & $\begin{array}{l}\text { Observation of } 35 \text { gynaecological surgeries } \\
\text { Observation of interruptions, degree of interference of } \\
\text { interruptions and their impact on performance and patient } \\
\text { safety }\end{array}$ & $\begin{array}{l}\text { Classification of interruptions } \\
\text { Visual } \\
\text { Auditory } \\
\text { CIC } \\
\text { Equipment problems } \\
\text { Non-theatre staff movement through theatre } \\
\text { Communication difficulties } \\
\text { Other } \\
\text { Interference of interruptions } \\
\text { Level I: minimal level of distraction } \\
\text { Level II: one member distracted } \\
\text { Level III: more than one member distracted }\end{array}$ & $\begin{array}{l}26 \text { interruptions per case } \\
90 \% \text { of interruptions occurred during the first } 30 \text { minutes } \\
\text { of the case } \\
\text { No correlation with surgical complications } \\
\text { Interruptions caused an increase of the operating time } \\
\text { of } \mathbf{1 8 . 4 6} \text { minutes }\end{array}$ \\
\hline Zheng et al. ${ }^{22}$ & Poor & $\begin{array}{l}\text { Observation of videos of } 12 \text { laparoscopic surgeries } \\
\text { Observation of interruptions and surgical delay caused by } \\
\text { them }\end{array}$ & $\begin{array}{l}\text { Classification of interruptions } \\
\text { Instrument change } \\
\text { Position change between surgeon } \\
\text { Duty shift of nurses } \\
\text { Conversation } \\
\text { Phone or pager answering } \\
\text { Extraneous interruptions }\end{array}$ & $\begin{array}{l}114 \text { interruptions per hour, only } 11 \% \text { provoked a delay } \\
\text { Most frequent categories of interruptions } \\
\text { Conversation: } 71 \text { per hour, without significant delay } \\
\text { Instrument change: } 33 \text { per hour, with a delay in } 11 \% \text { of } \\
\text { cases }\end{array}$ \\
\hline
\end{tabular}


Table B Example of interference classification of interruption in surgery

\section{Rating Observed effects}

1 Potentially distracting stimuli: events with the potential to distract the sterile team

2 Sterile team member momentarily distracted: possible involvement of a single sterile member in an event not related to the primary task, e.g., a short head turn in response to a visual or auditory stimulus

3 Sterile team member engages in distraction: similar distraction in 2, but the sterile member engages with the source of distraction by verbally responding while maintaining primary task activity (multitasking)

$4 \quad$ Sterile team member's primary task interrupted: a single team member ceases his/her current tasks to engage entirely in the distracting stimulus

$5 \quad$ Sterile team momentarily distracted: two or more sterile team members respond to a stimulus with a short head turn, no verbal response

$6 \quad$ Sterile team engage in secondary tasks: two or more team members engage with the source of distraction by verbally responding while maintaining primary task activity

7 Sterile team's work interrupted-operation flow disrupted: interruption of the current primary task of the sterile team, the operation flow is disrupted 